\title{
COMPARISON OF SLOVAK DAIRY PRODUCTS WITH AND WITHOUT ADDED VALUE SOLD BY COMMERCIAL CHAINS
}

\author{
Marek Petril'ák, Department of Marketing and Trade, Faculty of Economics and Management, Slovak university of agriculture in \\ Nitra, Trieda Andreja Hlinku 2, 94976 Nitra, Slovakia, xpetrilak@uniag.sk \\ Ing. Elena Horská, Department of Marketing and Trade, Faculty of Economics and Management, Slovak university of agriculture in \\ Nitra, Trieda Andreja Hlinku 2, 94976 Nitra, Slovakia, elena.horska@uniag.sk \\ Jozef Šumichrast, Head of office, Slovak Agriculture and Food Chamber, Vajanského 22, 91701 Trnava, Slovakia, \\ rppktt@stonline.sk \\ Jozef Palkovič, Department of Statistics and Operations Research, Faculty of Economics and Management, Slovak university of \\ agriculture in Nitra, Trieda Andreja Hlinku 2, 94976 Nitra, Slovakia, jozef.palkovic@uniag.sk (coresponding author)
}

\begin{abstract}
The share of products with higher added value is constantly decreasing in Slovakia's agri-food exports and the share of basic agricultural raw materials with low added value is increasing. Commercial retail chains sell especially products without added value. On the other side, products that have undergone a processing are imported from abroad. According to the latest survey of the Slovak Food Chamber of Agriculture in 2016, the share of Slovak products on retailers and retail chains is only $39.91 \%$, with $38.9 \%$ in 2015 and 2014 .with increase of only $1 \%$. Most of the agri-food products produced in Slovakia are at most represented in commodities: eggs, milk, honey and at least in the following categories: processed vegetables, packaged meat and processed fruit. The main objective of presented paper is to show, that Slovak farmers rather sell raw milk instead of selling added value processed products. A big difference can be found between milk and dairy products, where up to $20 \%$ is the difference in the representation of these products in the commercial chains. This fact means, that the Slovak farmers produce enough milk, but it is convenient for them to sell milk as a raw material instead of processing it in their own direction and selling the processed products. Raw milk is exported abroad and then comes back to the Slovak market with an added value as processed product. The survey, which was carried out on all trade chains, showed that the share of Slovak milk in the chain is $63 \%$. An important finding is also the presence of individual dairy products that are produced in Slovakia. The result of the survey showed that the largest share of Slovak dairy products in the domestic market is $51 \%$ cottage cheese and sweet / sour cream 55\% lowest ripening cheese $40 \%$ and processed cheese and cheese spread $43 \%$.
\end{abstract}

Keywords: milk, dairy products, commercial chains, added value, raw material

\section{INTRODUCTION}

Agricultural products at lowest market value cannot be sustainable, because they can effort growers to push their sources just to survive in economical way. Value added is anything what you can involve to the value of product in the market, it is everything producer can add to it which gives him possibility to increase his profit margin. The main key in future of sustainable farming is value added agricultural products practices, because they allow producers to leading economically without having to push the production of unprocessed materials (Clarg, 2004).

Specialized animal production and its development have two main positive impacts, namely at the first a high added value and in the contribution to growth. In particular, its development will make it possible to satisfy more specifically domestic demand, especially for products of high quality healthy nutrition. Specialized animal production also includes products made of goat, sheep, cow milk etc (KRP na rok 2013-2020). Sustainable dairy production requires farms that are economically feasible, environmentally fiendly and socially acceptable. Low impact of milk production on the environment is not necessarily related to an economically viable farm (Thomassen, 2009).

For example the US Department of Agriculture is counter to the idea of boost the production of homogeneous commodities to produce value-added products that can increase the profit of producers. One achievable way for producers to promote the sale of value-added products is to link these products to the region of origin of the product (Babcock, 2015). In our research, we investigated the relationship between domestic production of milk and milk products and their representation in Slovakia chain stores. Like we know milk is a source of very important essential nutrients and vitamins especcialy for developing baby which necessarily needs magnesium, calcium and vitamin D (Nicklas, 2009). Dairy products and milk are very important for our body because they help to keep it in a good shape, they support treatment of some diseases and also to prevent some of them. The consumption of milk is decreasing even of all possitive effects it has and thats why some organizations and nutrition professionals are trying to solve this problem (Habanová, 2010).

Copyright (C) 2017 The Authors. Published by Aleksandras Stulginskis University. This is an open-access article distributed under the terms of the Creative Commons Attribution License (CC-BY 4.0), which permits unrestricted use, distribution, and reproduction in any medium, provided the original author and source are credited. 
Representation of Slovak products in retail chains is important because Slovak products in general have superior quality trough quality policy. Nagyová (2010) pointed out that the main role of Quality policy is to keep the quality of agricultural products. This role is pushed by EU to increase the food quality and to implement it as a national tradition to countries of EU (Nagyová, 2011). World Health Organization (WHO) defines that the minimum consumption of milk per person should be at least $220 \mathrm{~kg}$ per year. Each person should consume at least 1 cup/day or an acid-based product (e.g. yoghurt, acidophilic milk) and 10dkg of cottage cheese or cheese (Kubicová, 2012). The Consumption in the Slovakia in 2015 was $169.2 \mathrm{~kg}$ per pound in net milk that makes $2.4 \mathrm{~kg}$ more (1.4\%) than in 2016 (Masár, 2017). As we mentioned Slovak consuption of milk and dairy products is $160 \mathrm{~kg} /$ person/year but in more developed countries of the consuption is 300 $\mathrm{kg} /$ person/year. Not only in the "western" Europe, but also in the "east", it is consumption of milk fermented beverages is about three times more and a minimum of twice more cheese as in Slovak Republic (SKAR, 2017). Among the Slovak inhabitans, yoghurts belong to the most typical and most common fermented milk products (Hylmar, 1986). The study of Kubalekova (2017) found that young generation has influence on dairy product with added value consumption mostly in the yogurts $29 \%$ and cheese almost $27 \%$. While the recommended consumption of milk as well as dairy products is actually set at the amount of $220 \mathrm{~kg} /$ person/year, the present scientific studies indicate that Slovaks consume just 160 $\mathrm{kg} /$ person/year. One of the options how to reverse this negative trend is actually raising the Slovak consumers awareness of the positive impacts of dairy products and product with added value product as yoghurts on the their health and called them fashionable food (Košičiarova, 2017). In 2004 Slovak Republic entered the EU. This step helped to remove the trade barriers and helped to increase export of milk and dairy products abroad. Even the shelf life of raw milk is short, producers had a perfect chance to benefit from very good trading conditions outside the country, especially by the borders at the south and west part of Slovak Republic. This step made a very competitive situation between Slovak dairies (Analýza slovenského obchodu s pol'nohospodárskymi a potravinárskymi výrobkami, 2015). Slovak open economy in the international market has an influence on a milk production and the dairy industry in Slovak Republic. The results of Eurostat from 2016 show that Slovakia was $0.56 \%$ of total milk production in the EU (EUROSTAT-Production of milk on farms, 2016). Production of cow's milk in Slovakia in 2015 increased by $0.9 \%$ to 957.4 thousand (Správa o pol'nohospodárstve a potravinárstve v SR, 2015). If Slovak Republic compare share of total milk production in the EU with Czech Republic which is also small player in dairy production in the European Union only about $1.7 \%$ of the total EU milk volume is supplied by Czech dairy farms (thuenen.de, 2017).

\section{MATERIAL AND METHODS}

Data about production were obtained from the database of Slovak research institute of agricultural and food economics. They cover production of milk and milk processed products in thousands of tons for the period of years $2006-$ 2016. Database includes following variables: raw milk, processed milk (for consumption), raw cheese, molten cheese, cream and yogurt.

First, data were collected and processed. Then, current situation on the market was described using charts and basic descriptive statistics. To determine relationship between production of milk and other products was used correlation analysis.

In this case was used Pearson's correlation coefficients, which can be calculated using following equation:

$$
\rho_{x y}=\frac{\operatorname{cov}(X, Y)}{\sigma_{X} \sigma_{Y}}
$$

Where $\operatorname{cov}(\mathrm{x}, \mathrm{y})$ is the covariance between $\mathrm{x}$ and $\mathrm{y}$, and $\sigma_{X}$ is the standard deviation of $\mathrm{X}$ and $\sigma_{Y}$ is the standard deviation of Y. Correlation coefficient values close to 0 means weak or no relationship between variables. Value close to 1 means strong positive relationship - if the first variable increase, increase also second variable. Value close to -1 means strong negative relationship - if the first variable increase, second one decrease. Correlation analysis i sused only to determine character of relationship between pair of variables, not to determine which variable is the cause and which is the consequence.

Significance of the correlation coefficient can be teste using test statistics in form:

$$
t=r \sqrt{\frac{n-2}{1-r^{2}}}
$$

Hypothesis in this case are as follows: H0: Correlation coefficient is not significantly different from 0

H1: Correlation coefficient is significantly different from 0 (significant relationship between variables).

Result is compared with the critical value of $t$ distribution with level of significance alfa and $n-1$ degrees of freedom. If the test statistics exceeds critical value $\mathrm{H} 0$ is rejected and relationship between variables is significant, if the test statistics is smaller than critical value, $\mathrm{H} 0$ is accepted and there is no significant relationship between variables.

Test can be evaluated also using value corresponding to test statistics and its comparing with the significance level. If the value is smaller than alfa, $\mathrm{H} 0$ is rejected, if the pvalue exceeds the significance level, $\mathrm{H} 0$ is accepted with the same meaning as was mentioned abave.

\section{RESULTS}

Table 1 shows characteristics of the milk production and also of the production of the value added products from processed milk. Highest values of production was recorded in case of milk for consumption. Highest variability of data measured by coefficient of variation was recorded in case of raw and molten cheese. On the other side, in general, it can 
be concluded smal variability in the production of milk products. In case of molten cheese, yougurt and milk for consumption, production values occurs mostly above the average values, in case of raw cheese and cream is most of the data below the average.

Tab. 1 Characteristics of the data

\begin{tabular}{|l|c|c|c|c|c|c|}
\hline production in 1000 tons & milk(drinking) & raw cheese & molten cheese & cream & yogurt & raw milk \\
\hline Mean & 275.96 & 36.98 & 10.69 & 32.48 & 57.24 & 978.17 \\
\hline Median & 276.71 & 35.16 & 11.26 & 32.25 & 54.43 & 957.30 \\
\hline Standard Deviation & 29.06 & 5.44 & 1.58 & 2.87 & 6.59 & 63.73 \\
\hline coef. Of variation & $11 \%$ & $15 \%$ & $15 \%$ & $9 \%$ & $12 \%$ & $7 \%$ \\
\hline Kurtosis & -1.14 & 0.26 & -0.52 & 0.87 & -1.92 & -0.61 \\
\hline Skewness & 0.31 & 0.90 & 0.20 & -0.05 & 0.14 & 1.08 \\
\hline Minimum & 238.33 & 29.90 & 8.46 & 27.10 & 48.68 & 918.00 \\
\hline Maximum & 321.53 & 47.88 & 13.64 & 37.89 & 66.41 & 1091.70 \\
\hline
\end{tabular}

Comparison of the raw milk production, and its processed version for consumption is on the figure 1. Production of raw milk in recent years had decreasing tendency with the maximum in 2006 when was produced 1091 thousands tons of raw milk. On the other side, lowest production of raw milk was recorded in 2010 with the value 918 thousands of tons. Production of processed milk for the consumption had increasing tendency until 2013, when was produced 321 thousands of tons milk for the consumption. Since this year tendency changed again to decreasing trend.

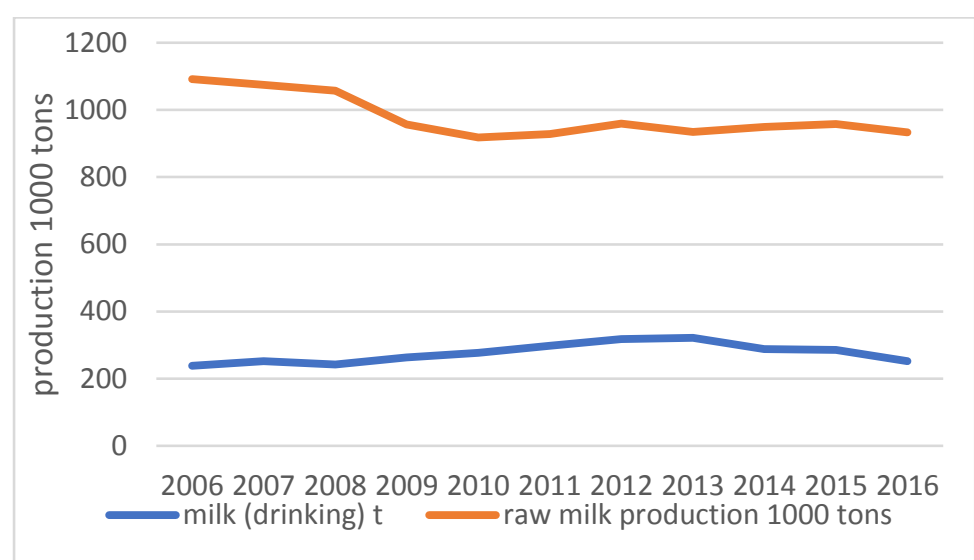

Figure 1. Comparison of raw milk and milk for theconsumption

Production of other value added produced from processed milk is much smaller than it was in case of milk. To make it easier to understand, it is show on the figure 2. In case of molten cheese is the production stable with slow decrease, but without any significant trend. Production of yogurts recorded increasing tendency in the analysed period. The most variable is the production of molten cheese which recorded decrease from 2006 until 2010. After this year trend changed to increasing and still continues in this tendency.

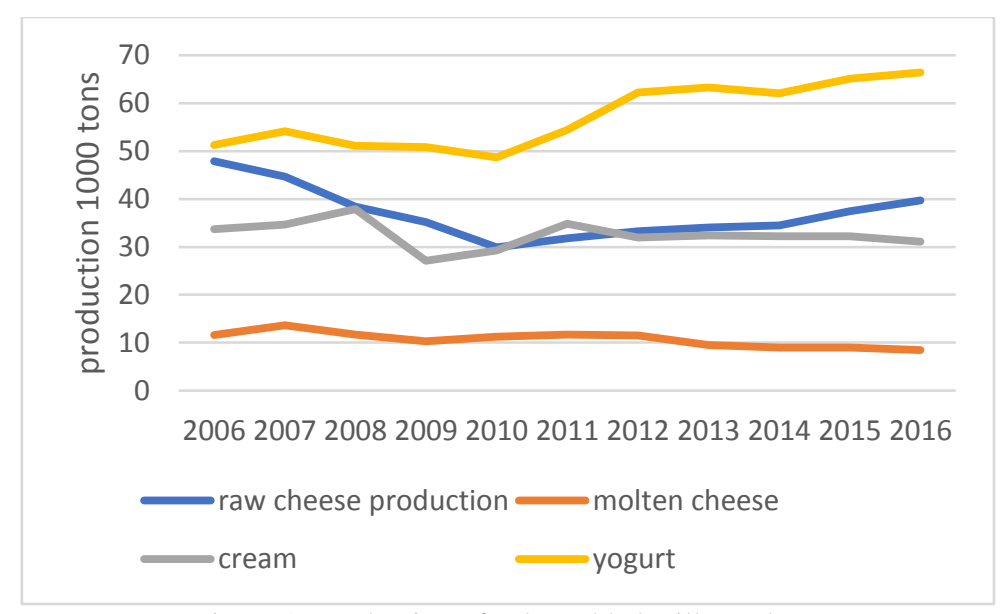

Figure 2. Production of value added milk products 
When we compare production of milk for the consumption and production of other value added products from processed milk, it is obvious significant share of consumption milk production from the production of total raw milk. Figure 3 shows the comparison of share of milk for the consumption and share of other value added products on total raw milk production. At the begining of the analysed period was only $22 \%$ of milk intended for the consumption. This share was increasing until 2013, when more than 34\% of milk production was processed for the direct consumption and only $66 \%$ processed as other value added milk products. Since 2013 trend changed and share of milk for the consumption continue in decrease. Situation in 2016 when was processed $73 \%$ of milk as value added products was still significantly different from the initial year 2006, when it was processed more than $78 \%$ of milk as the value added milk products.

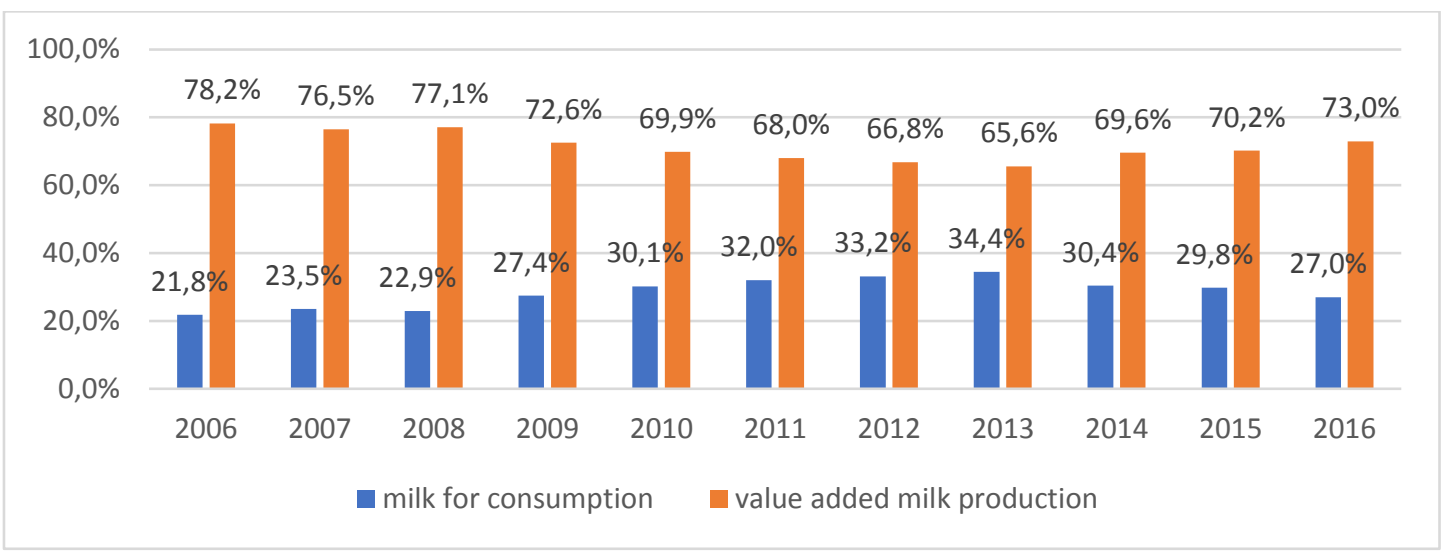

Figure 3. Comparison of share of milk for consumption and value added products on total raw milk production

There is a quastion which value added products substitutes the consumption milk production the most. It can be answered by estimating relationship between consumption milk production and other value added production on the figures below (figures 4,5,6,7). Graphical analysis suggests strongest relationship between milk and raw cheese production which could be possible substitute for milk production in year of decrease its share. Molten cheese could be also related to consumption milk production, but this relationship does not seems to be strong. Production of cream and yougurt seems to be clearly independet from the production of milk for the consumption.

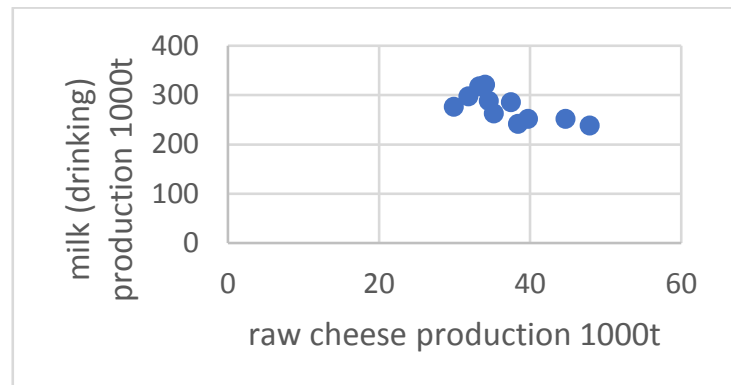

Figure 4. Milk vs raw cheese

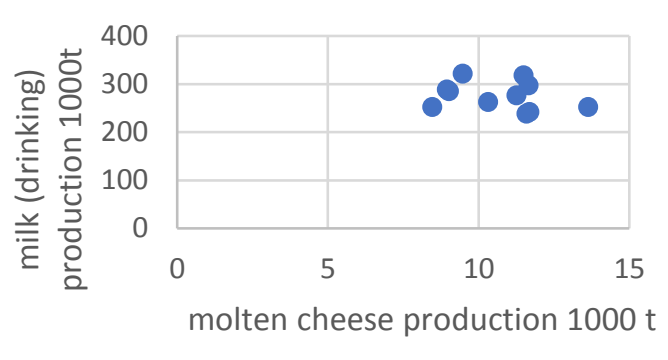

Figure 5. Milk vs molten cheese

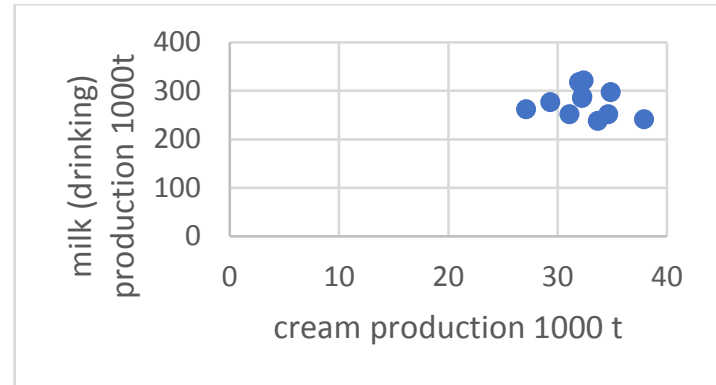

Figure 6. Milk vs cream

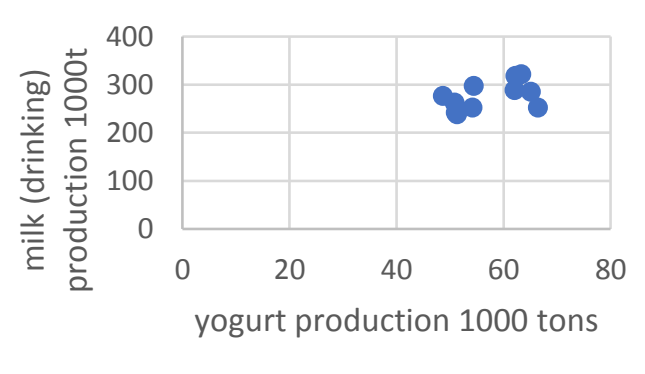

Figure7. Milk vs yogurt production

To verify results of the graphical analysis was calculated correlation matrix. This includes Pearson's Correlation coefficients and contains values only under diagonale because values above the diagonal would be the same. Highlighted values means significant correlations. There is strong significant negative relationship between consumption milk production and raw cheese production. On the other side, there is interesting negative correlation between raw milk production and production of milk for the consumption. This fact could possibly mean that increase of raw milk production does not increase production of milk for the consumption, but this increase goes mostly to raw and molten cheese production according to results in table 2. 
Table 2 Pairwise correlations of milk products

\begin{tabular}{|c|c|c|c|c|c|c|}
\hline & milk (drinking) $t$ & $\begin{array}{l}\text { raw cheese } \\
\text { production }\end{array}$ & $\begin{array}{l}\text { molten } \\
\text { cheese }\end{array}$ & cream & yogurt & $\begin{array}{c}\text { raw milk production } \\
1000 \text { tons }\end{array}$ \\
\hline milk (drinking) $t$ & 1 & & & & & \\
\hline raw cheese production & $-0,705276512$ & 1 & & & & \\
\hline molten cheese & $-0,256705854$ & 0,2751 & 1 & & & \\
\hline cream & $-0,190827059$ & 0,3595 & 0,42021 & 1 & & \\
\hline yogurt & 0,483919516 & $-0,084$ & $-0,6833$ & 0,0591 & 1 & \\
\hline $\begin{array}{l}\text { raw milk production } 1000 \\
\text { tons }\end{array}$ & $-0,669422832$ & 0,8514 & 0,61388 & $\begin{array}{r}0,5714 \\
9\end{array}$ & $-0,416$ & 1 \\
\hline
\end{tabular}

The last step in conducted analysis was the relationship between production of processed value added milk products and the share of domestic products in commercial retail chains. Data were collected only for last two years and no significant changes can be seen. But it could be also the suggestion for the further reasearch. Share of domestic products in the retail chains is probably long run relationship, because it is influenced also by supplier relations and contracts, this situation can change probably in horizont of more years.

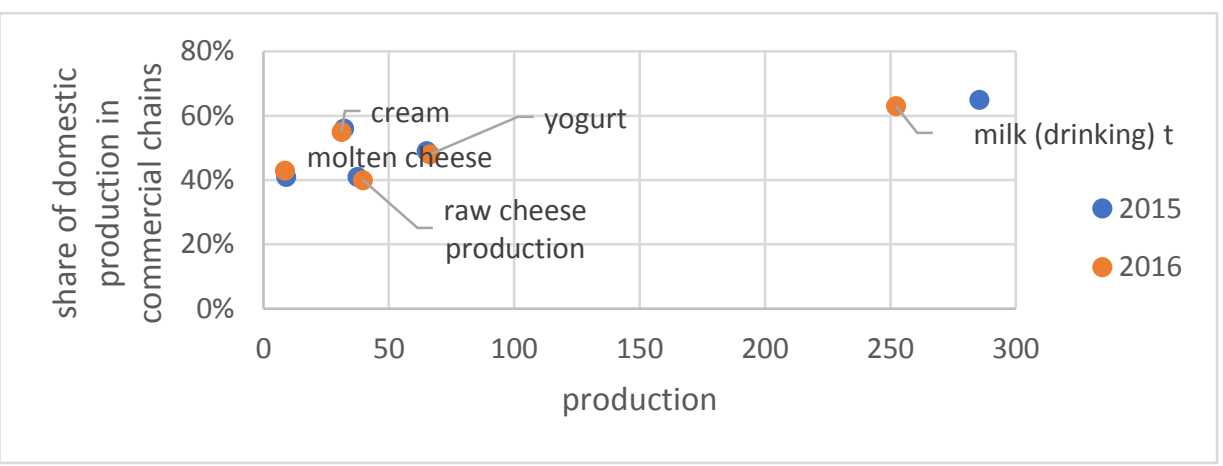

Figure 8. Relationship between production of processed value added milk products and the share of domestic products in commercial retail chains

Research was conducted in all slovak commercial chains. Based of the research our market showed the biggest representation of Slovak dairy products except raw cheese is COOP Jednota and CBA, which are retail chains with registered capital of Slovakia. In terms of the below, the share of Slovak milk in the retail chains decrease year on year by $2 \%$, while even with sufficient production, we still import $37 \%$ of consumption milk from abroad. The lowest amount of domestic products has raw cheese $40 \%$ and molten cheese $43 \%$. All dairy products and also consumption milk noted decreasing in last year, except molten cheese which the year-on-year increase was $2 \%$. According research, we assume that this occurred due to a $3 \%$ year-on-year decrease in consumption milk production.

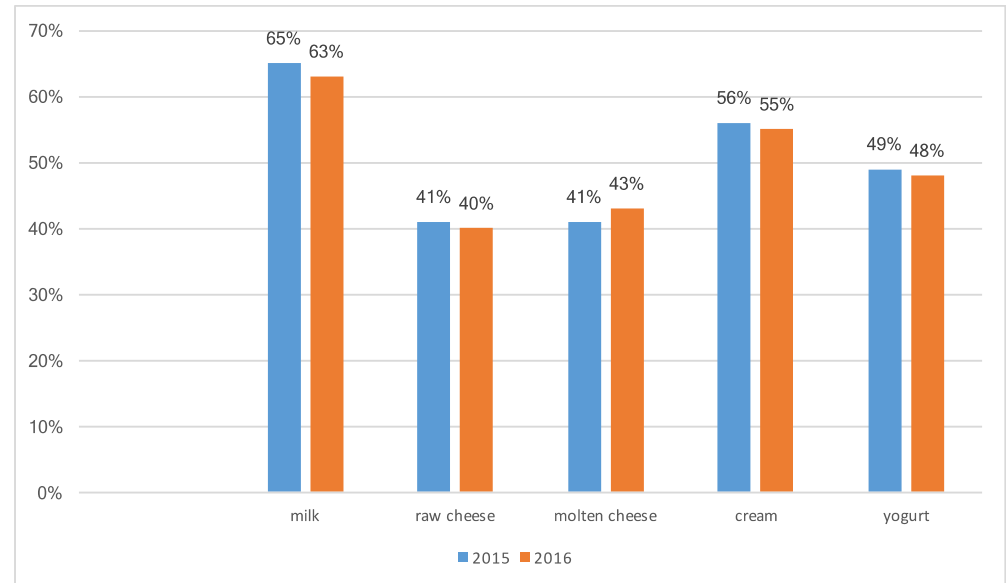

Figure 9. Comparison of the share of milk and dairy products in Slovak retail chains in 2015 and 2016

\section{CONCLUSIONS}

As we mentioned, the representation of domestic products on the shelves of the retail chains is important for the sustainability of agriculture in Slovakia. If will be more domestic value added products in Slovak market the more farmers will not just produce raw material but also process it. We studied the dependence of milk production on consumption and the milk used to produce added-value products and their share in total production. It is important to identify the relationship between raw milk production and the milk value added products. Analysis shows relationship between the 
production of raw cheese, melt cheese, cream and yogurt, the consumption of milk and the total milk production, which showed that there is a stronger relationship between milk and raw cheese production. Production of cream and yougurt seems to be clearly independat from the production of milk for the consumption

Relations shows that increase of raw milk production does not increase production of milk for the consumption, but this increase goes mostly to raw and molten cheese production. Comparison of share of milk for the consumption and share of other value added products on total raw milk production. Situation in 2015 when was processed only $70 \%$ of milk as value added products than in 2016 when was processed $73 \%$ of milk as value added products was significantly different from the initial year 2006, when it was processed more than $78 \%$ of milk as the value added milk products. When we compared research in retails chains with production of milk value added products, we can see that the share of domestic products in 2015 and 2016 has fallen by $3 \%$, with the share of added value added milk increasing by $3 \%$ in total production The highest representation cream products have $55 \%$ at which it was recorded an annual decrease of $1 \%$. The lowest representation in dairy products has raw cheese $40 \%$ where the year-on-year increase was also $1 \%$. Following of results of our research, we know that is strong relation between milk for the consumption and molten cheese, the percentage of milk decreased by $2 \%$ while molten cheese increased by $2 \%$, this fact can be demonstrated a strong relationship between the two products. We assume that a large influence on the placing on the shelves of retail chains has export and import of milk and milk products. Therefore, we recommend to examine this issue in more detailed survey of this topic.

\section{ACKNOWLEDGEMENTS}

The paper is a part of the research project APVV-16-0244 "Qualitative factors affecting the production and consumption of milk and cheese", solved at the Department of Marketing and Trade, Faculty of Economics and Management, Slovak University of Agriculture in Nitra.

\section{REFERENCES}

1. Babcock, B. A., 2015. Geographical Indications, Property Rights, and Value-Added Agriculture. Iowa Ag Review, Vol. 9 , Iss. 4.

2. Elevitch, C.R, 2004. The Overstory Book: Cultivating Connections with Trees, Permanent griculture Resources ISBN 9780970254436, 2004

3. European commission, 2016. Production of milk on farms. Avialable at: http://ec.europa.eu/eurostat/web/products-datasets/-/tag00041

4. Habanová, M., Lorková, M., Kopčeková, J. 2010. The consumption of acidophylus drinks and yogurts in selected population of pupils in years 2004 and 2008. In Potravinárstvo, Vol. 4, No. 3, pp. 19-23.

5. Hylmar.B. 1986.Výroba kysaných mléčných výrobků. Praha: SNTL. [In Slovakian]

6. Košičiarová, I., Nagyová, L., Holienčinová, M. 2017. Consumer Behaviour on Slovak Yoghurt and Fermented Milk Products Market. Acta Universitatis Agriculturae et Silviculturae Mendelianae Brunensis, Vol. 65(6), pp. 1967-1978. https://doi.org/10.11118/actaun201765061967

7. Kubaleková, A., Šugrová, M. Habit or choice? The decision - making process of young generation in purchasing dairy products in the Slovak Republic. In International Day of Science 2017 - Economics, Management, Innovation, pp. 113-120.

8. Kubicová,L'., Dobák, D. 2012. Vývoj a úroveň spotreby mlieka a mliečnych výrobkov v SR a modelovanie dopytu po potravinách vo vybraných skupinách domácnosti, SPU v Nitre 2012. [In Slovakian]

9. Masár I.. 2017. Mlieko. Situačná a výhl’adová správa 1, pp. 5, NPPCVUPP 2017 [In Slovakian]

10. Ministry of Agriculture and Rural Development Slovak Republic 2013, Koncepcia rozvoja pôdohospodárstva na roky 2013-2020.

11. Ministry of Agriculture and Rural Development Slovak Republic. 2015. Analýza slovenského obchodu s pol’nohospodárskymi a potravinárskymi výrobkami. Availible at: http://www.mpsr.sk/index.php?navID=612\&navID2=612\&sID=111\&id=8993 [In Slovakian]

12. Ministry of Agriculture and Rural Development Slovak Republic. 2016. Správa o pol'nohospodárstve a potravinárstve v SR 2015, Available at: http://www.vuepp.sk/dokumenty/zelena/zelena2016.pdf [In Slovakian]

13. Nagyová L., Horská E., Kadeková Z., 2011, Food quality policy and labelling. Delhi Business Review, Vol. 12 , p. 85.

14. Nicklas, T.A., O’Neil, C.E., Fulgoni, V.L. 2009. The role of dairy in meeting the recommendations for shortfall nutrients in the American diet. Journal of the American College of Nutrition, Vol. 28, Iss. 1, pp. $73 \mathrm{~S}-81 \mathrm{~S}$ https://doi.org/10.1080/07315724.2009.10719807

15. SKAR. 2017. Mlieko. Available at: http://www.mlieko.sk (Accessed on 25/02/2018).

16. Thomassen, M.A., Dolman, M.A., Van Calker, K.J., De Boer, I.J.M. 2009. Relating life cycle assessment indicators to gross value added for Dutch dairy farms. Ecological Economics, Vol. 68(8), pp. 2278-2284. https://doi.org/10.1016/j.ecolecon.2009.02.011

17. THUNEN. 2017. Dairy farming in Czech Republic. Available at: www.thuenen.de/media/institute/bw/Startseite_Aktuelles/Aktuelles_17-07_EDF_Kongress_Prag.pdf (Accessed on 25/02/2018). 